\title{
Perspective on Stem Cells in Developmental Biology, with Special Reference to Neuroendocrine Systems
}

\author{
Karine Rizzoti, Carlotta Pires, and Robin Lovell-Badge
}

\begin{abstract}
In the embryo, organs gradually take shape as tissue progenitors, proliferate, differentiate and are organised, via cellular interactions, in tri-dimensional functional structures. Most adult organs retain a cell population sharing important similarities with embryonic progenitors, which includes the ability to both selfrenew and to differentiate into the full range of the specialised cell types corresponding to the organ in which they reside. These two essential properties define them as adult stem cells (AdSC). Their characterization in different contexts provides a better understanding of cell turnover modalities for organ function, which is important for tumorigenesis, because adult tissue stem cells can give rise to cancer stem cells. However, it is also relevant to regenerative medicine, because stem cells can be transplanted or manipulated in vivo to restore missing cells. The successful reprogramming of somatic cells into induced pluripotent stem cells (iPSC) (Takahashi and Yamanaka, Cell 126:663-676, 2006), resembling pluripotent embryonic stem cells (ESC), opened alternative strategies for cell replacement. The required cell type can be differentiated in vitro from expandable progenitors and transplanted where required. This approach is particularly promising, because genetic defects can potentially be repaired in vitro prior to their engraftment; moreover, a large number of cells can be produced (Fox et al., Science $345: 1247391,2014)$. However, the transplanted cells have to be able to functionally integrate into the deficient organ. To potentially alleviate this problem, tri-dimensional culture systems have been recently developed where mini-organs, or organoids, can be obtained in vitro. These also represent unique models for disease modelling and drug screening (Huch and Koo, Development 142:3113-3125, 2015). Within neuroendocrine systems, the hypothalamo-pituitary axis has a crucial role for body homeostasis. It also regulates functions such as growth, reproduction, stress and, more generally, metabolism. The hypothalamus centralizes information from the periphery and other brain regions to regulate pituitary hormone secretions and to control appetite, sleep and aging. Its functions
\end{abstract}

\footnotetext{
K. Rizzoti $(\bowtie) \cdot$ R. Lovell-Badge $(\varangle)$

The Francis Crick Institute, Mill Hill Laboratory, The Ridgeway, London NW7 1AA, UK

e-mail: karine.rizzoti@crick.ac.uk; robin.lovellbadge@crick.ac.uk

C. Pires

University of Copenhagen, Gronnegaardsvej 7, Frederiksberg 1870, Denmark
}

D. Pfaff, Y. Christen (eds.), Stem Cells in Neuroendocrinology, Research and

Perspectives in Endocrine Interactions, DOI 10.1007/978-3-319-41603-8_11 
are exerted through secretion of neurohormones and manipulation of these could be of interest not only for the treatment of obesity and sleep disorders but also to alleviate aging-related conditions. Pituitary hormone deficiencies can originate from defects affecting the hypothalamus, pituitary, or both. Today these deficiencies are treated by substitution or replacement therapies, which are costly and have side effects. AdSC have recently been characterized in the hypothalamus and pituitary (Castinetti et al., Endocr Rev 32:453-471, 2011; Bolborea and Dale, Trends Neurosci 36:91-100, 2013). Moreover, hypothalamic neurons and pituitary endocrine cells have been differentiated in vitro from ESC and iPSC and successfully transplanted. These promising routes for development of regenerative medicine to restore or manipulate the function of the hypothalamo-pituitary axis will be discussed here, and further challenges considered.

\section{Introduction}

It is now clear that multipotency, once thought to be largely restricted to embryonic stages and to a few stem cell types in the adult, is preserved postnatally, as most adult tissues comprise a population of undifferentiated cells. These are characterized by their ability to undergo asymmetric divisions, underlying self-renewal and an ability to have differentiated cell progeny, the two essential properties of stem cells. Pluripotency, the ability to produce all adult cell types, can be "recovered" in vitro by reprogramming somatic cells into induced pluripotent stem cells (iPSC; Takahashi and Yamanaka 2006). In addition, transdifferentiation to another cell type or to multipotency can be forced onto differentiated cell types by activating expression of specific factors or via cell fate conversion with chemicals and/or growth factors (Vierbuchen and Wernig 2012). While these discoveries are by themselves challenging our view of cellular plasticity and its limits, for medicine they mean that therapies can progress from or incorporate both a pharmacological approach and a cellular one, where abnormal, deficient or entirely missing cells can be replaced (Fox et al. 2014). Cellular reprogramming implies, in particular, the possibility of autologous transplantation, alleviating at least some aspects of immune rejection that, in conjunction with genome editing tools (Hsu et al. 2014), hold great promise for deriving, repairing, differentiating and transplanting back functional, patient-specific cells. In addition, the derivation of patient-specific cells by itself represents a great advance toward in vitro disease modelling and drug screening (van de Wetering et al. 2015). In the clinic, some promising results have already been obtained in pilot studies using retinal pigment cells derived from human ESC (Schwartz et al. 2015), but other trials have also highlighted the many challenges to be overcome (Steinbeck and Studer 2015). It is likely that further development of three-dimensional (3D) organoids (Huch and Koo 2015) and tissue engineering, combining several different cell types for 
formation of vascularized mini-organs, will greatly enhance transplantation efficiency and functional repair (Shamir and Ewald 2014). Finally, another important aspect to consider for use of these therapies is the financial one. Numerous qualitative criteria have to be satisfied to allow clinical use of stem cells. Currently, and for good reasons, these criteria have to be stringent (French et al. 2015) and therefore expensive. Although experience, scaling up, and automation might lead to a relaxation of requirements and to reduced costs, we still need to question today how feasible it will be to routinely offer such treatments in the future. It would be unfair if treatments were only available to the very privileged few.

We will focus our attention here on stem cells of the hypothalamo-pituitary axis, and why and how these could be used for regenerative medicine. The hypothalamopituitary axis, while a crucial regulator of homeostasis, also ensures that the organism responds appropriately to changing physiological situations such as puberty, pregnancy, lactation, and stress. While many hypothalamic roles are executed through the pituitary, with the seven different hormones secreted by the gland affecting most physiological processes, some hypothalamic neurons also directly interact with other regions of the brain to control appetite (Schneeberger et al. 2014), sleep and wakefulness (Konadhode et al. 2014). Finally, it has recently been proposed that systemic aging is initiated in the hypothalamus (Zhang et al. 2013). Consequently, pathological situations leading to hypothalamic and/or pituitary hormone imbalance have pleiotropic consequences, resulting in significant morbidity and even mortality. These can be congenital or acquired and originate from a defective pituitary, hypothalamus or both; moreover, in most cases they are of unknown aetiology (Kelberman et al. 2009). The most frequent congenital defect is isolated growth hormone deficiency, with a prevalence of 1 in 3500-10,000 births (Kelberman et al. 2009). Later in life, acquired deficits develop mainly as a consequence of pituitary tumors, mostly affecting lactotrophs, or from brain damage (Hannon et al. 2013). Hormone substitution or replacement therapies are available to treat pituitary deficiencies. However, these are not optimal, first because they do not reproduce normal physiological secretion patterns, secondly because they are associated with side effects (Alatzoglou et al. 2014), and thirdly, they are not inexpensive; hGH treatment in the UK costs up to $£ 12,000 /$ year for children in whom treatments can last for several years. Being able to provide secreting endocrine cells would, therefore, represent a significant advance, particularly for pediatric patients where the pituitary is primarily affected but perhaps also for those where an hypothalamic deficiency is thought to be responsible, such as Prader-Willi syndrome, or more generally where a hypothalamic defect leads to formation of an underdeveloped pituitary gland (Rizzoti et al. 2004). Pituitary hormones can, in turn, also feed back on the formation of hypothalamic neuronal circuitry (Sadagurski et al. 2015); therefore, they may be able to improve some hypothalamic defects. Manipulating or restoring hypothalamic function would be beneficial in cases of infertility and obesity, which has already been shown using cell or tissue transplants (see below), but also for sleep disorders; importantly, it might lighten some age-associated conditions. 
In this perspective we will first briefly describe the morphogenesis of the ventral diencephalon, from which the hypothalamus derives, and of Rathke's pouch (RP), the pituitary anlagen. The transition between tissue progenitor and stem cell phenotype will then be discussed in the context of the developing pituitary. Recently, populations of AdSCs have been described and partially characterized in both compartments of the axis (Lee et al. 2012; Li et al. 2012; Andoniadou et al. 2013; Haan et al. 2013; Rizzoti et al. 2013; Robins et al. 2013a, b; Castinetti et al. 2011) and their characterization will be presented here, with reference to other chapters of this book. Finally, exciting progress has been made toward the use of stem cells for regenerative medicine in the axis: both hypothalamic neurons (Wataya et al. 2008; Merkle et al. 2015; Wang et al. 2015) and pituitary endocrine cells (Suga et al. 2011; Dincer et al. 2013) have been obtained in vitro from stem cells and successfully transplanted in mice. We will discuss these reports and the future challenges toward clinical use of stem cells in the hypothalamo-pituitary axis.

\section{Morphogenesis of the Hypothalamo-Pituitary Axis (Fig. 1)}

\section{Hypothalamus}

In the embryo, the hypothalamus develops from the ventral diencephalon. During the specification of the neural plate, at 8 days post-coitum (dpc) in mice, the prospective ventral diencephalon is situated at the midline, in the rostral-most position. It is in contact with the future pituitary, which is present as the hypophyseal placode at this stage, in the adjacent ectoderm at the anterior neural ridge (see below). As the neural plate bends to close (McShane et al. 2015), increased proliferation of the telencephalic progenitors versus those in the ventral diencephalon causes an apparent posterior shift of the prospective hypothalamus, located ventrally and posterior to the telencephalic vesicles in 9.5-dpc mouse embryos. A localized evagination of the ventral diencephalon toward the underlying developing pituitary becomes apparent at $9.5 \mathrm{dpc}$. From this particular region, called the infundibulum, the median eminence (ME), pituitary stalk and pituitary posterior lobe will develop. The ME, located at the floor of the third ventricle, is a circumventricular organ, which means that the blood-brain barrier is interrupted at its level. Hypothalamic neuro-hormones collect here into a bed of fenestred capillaries belonging to the hypohyseal portal system, which then transport them to the pituitary. Within the ME, special glial cells, the tanycytes, regulate neurohormone secretion at the axon termini levels (Prevot et al. 2010). These also integrate peripheral information by, for example, sensing glucose concentration and responding to thyroid hormone (Bolborea and Dale 2013; Ebling 2015). Moreover, and importantly, at least a proportion of tanycytes have been shown to comprise hypothalamic stem cells (see below). These cells therefore perform crucial regulatory roles at this bloodbrain interface in the short term, by regulating neurohormone secretion, but also in the long term, by modulating hypothalamic cell numbers. Some hypothalamic 


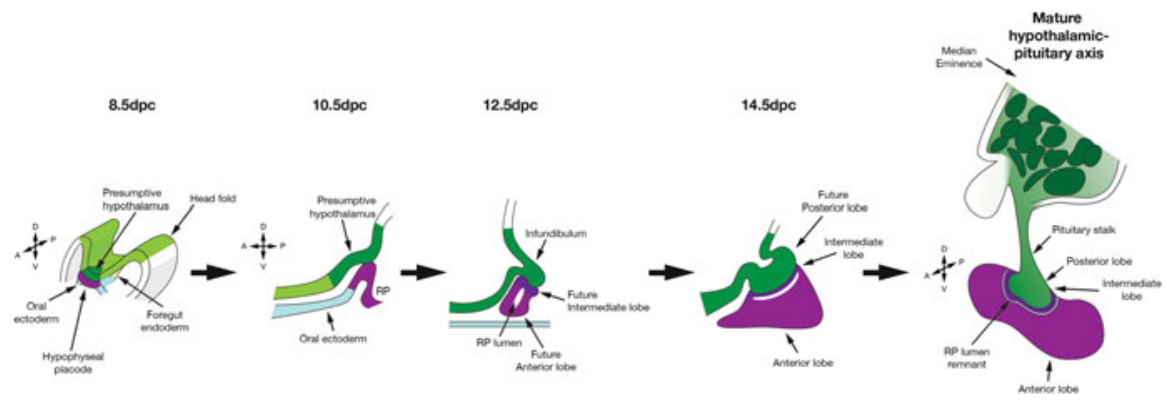

Fig. 1 Development and function of the murine pituitary-hypothalamic axis. Rostral to the presumptive hypothalamus, pituitary development is initiated with the appearance of the hypophyseal placode at $8.5 \mathrm{dpc}$ in the mouse. At $9.5 \mathrm{dpc}$, the placode invaginates to become the Rathke's pouch (RP). Within the diencephalon, the infundibulum evaginates towards RP by 10.5 dpc. It will give rise to the median eminence (ME), the pituitary stalk and the posterior lobe, whereas the anterior and intermediate lobes originate from RP. Gradually, hypothalamic neurons forming the different nuclei differentiate. Postnatally, the hypothalamus centralizes peripheral information and controls, through release of hypophysiotropic hormones, pituitary endocrine secretions. Hypothalamic peptide hormones can reach the gland directly, such as oxytocin and vasopressin secreted directly in the posterior lobe, or via the hypophyseal portal system. Hypothalamic neuropeptides $(\mathrm{GnRH}$, gonadotrophin releasing hormone, GHRH GH releasing hormone, TRH TSH releasing hormone, $C R H$ corticotropin releasing hormone and the inhibitory SST, somatostatin) are secreted at the ME and collected by capillaries. Anterior pituitary endocrine cells comprise lactotrophs (producing prolactin, Prl), gonadotrophs (producing luteinizing hormone, $\mathrm{LH}$, and follicle stimulating hormone, FSH), thyrotrophs (producing thyroid stimulating hormone, TSH), corticotrophs (producing adenocorticotropic hormone, ACTH, proteolytically cleaved from proopiomelanocortin, POMC) and somatotrophs (producing growth hormone, GH). Adapted from Rizzoti (2015)

neurons, namely those secreting oxytocin and vasopressin, reach directly into the posterior lobe of the pituitary; their axons, along with the portal system capillaries, are located within the pituitary stalk. Pituicytes, glial cells present both in the stalk and posterior pituitary, are proposed to regulate neurosecretion at these levels. Tanycytes and pituicytes both originate from the infundibulum, and no neurons are produced in this domain (Goto et al. 2015). The specification of the infundibulum in the embryo is complex and relies on an antagonism between members of the bone morphogenetic protein (BMP) family, present in the future infundibulum, and the secreted molecule Sonic Hedgehog ( $\mathrm{SHH}$ ), which is excluded from it (Zhao et al. 2012; Trowe et al. 2013). Members of the fibroblast growth factor (FGF) family are in turn required for infundibular cell expansion (Pearson et al. 2011). The transcription factor LHX2 is necessary for formation of the infundibulum in the embryo and later on for expression of the RAX transcription factor, which is essential for ventro-medial hypothalamic development ( $\mathrm{Lu}$ et al. 2013) and the emergence of tanycytes (Salvatierra et al. 2014). The NOTCH pathway is also required for correct morphogenesis of this region (Goto et al. 2015), but it is unclear at present how these different signalling pathways are integrated. 
As neurogenesis takes place, hypothalamic neurons differentiate and migrate to form groups of neurons, or nuclei. Nuclei located the furthest away from the third ventricle are formed first, whereas the latest to differentiate are closest. The GnRH neurons are the only exception, as these originate from the olfactory placode and migrate through the developing brain to reach their destination around the ME, where they control reproductive function (Stevenson et al. 2013) and aging (Zhang et al. 2013). Each nucleus regulates different physiological functions, such as circadian rhythms by the supra-chiasmatic nucleus or feeding behaviour by the arcuate. Hypothalamic morphogenesis is complex because of its organization, which lacks clear morphological landmarks; this explains why we know comparatively less about it compared to other regions of the brain where the anatomy is somehow simpler. Mechanisms of hypothalamic neurogenesis are beyond the scope of this perspective and have been recently comprehensively reviewed (Bedont et al. 2015; Pearson and Placzek 2013).

\section{Pituitary}

The first sign of pituitary development is the appearance at $8 \mathrm{dpc}$ of an ectodermal thickening in the rostral-most position, in the anterior neural ridge just in front of the future ventral diencephalon. This domain, the hypophyseal placode, forms along with the olfactory, optic and otic placodes (Soukup et al. 2013; Schlosser et al. 2014). As the presumptive diencephalon is apparently shifted posteriorly at $9.5 \mathrm{dpc}$, the hypophyseal placode is present just underneath and has become the pituitary anlagen or RP. RP is an epithelial invagination that forms in continuity with the oral ectoderm and extends dorsally toward the ventral diencephalon. RP is also in contact with the anterior border of foregut endoderm (Khonsari et al. 2013), and both dorsally and ventrally secreted signals are crucial for proper RP morphogenesis. SHH, independently of its role for formation of the infundibulum, is required for RP development, but it is not expressed in the pouch (Wang et al. 2010). The infundibulum is crucial for induction and maintenance of the pouch at these early stages, predominantly through secretion of BMP and FGF signals, respectively (Ericson et al. 1998; Treier et al. 1998). RP grows rapidly and by $11.5 \mathrm{dpc}$ it also separates from the oral ectoderm. The three pituitary lobes do not have the same embryonic origin because anterior and intermediate lobes are RP derivatives, whereas the posterior one has a neurectodermal origin.

As development progresses, the main wave of cell cycle exit in the developing pituitary, correlating with endocrine cell commitment and differentiation, occurs between 11.5 and 13.5 dpc (Japon et al. 1994; Davis et al. 2011). As cells exit the cell cycle, they adopt more ventral and lateral locations and loose epithelial characteristics, reminiscent of epithelial to mesenchymal transition (Himes and Raetzman 2009). Endocrine cells then gradually organize in homotypic endocrine networks, resulting in more efficient and coordinated hormonal secretion in the adult (Mollard et al. 2012). Pituitary cell fate specification is also discussed in Drouin (2016). 
In rodents, the gland will undergo a phase of important growth during the first weeks of life. This is characterized by high levels of proliferation, both in progenitors and in endocrine cells. Endocrine cells retain the capability to proliferate throughout life, but they do so rarely (Levy 2002). After birth, the hypothalamus will take control of pituitary endocrine maturation, secretions, and perhaps also stem cell homeostasis, but it is not clear exactly when and how its influence starts to be exerted.

\section{Transition Between Tissue Progenitor and Stem Cell Phenotype in the Developing Pituitary}

Early RP progenitors express the transcription factor SOX2 (Fauquier et al. 2008), and lineage-tracing experiments using a Sox $2^{\text {creERT2 }}$ allele have shown that SOX2positive progenitors give rise to all endocrine cell types in the pituitary (Andoniadou et al. 2013; Rizzoti et al. 2013). In addition, embryonic progenitors give rise to adult pituitary stem cells (Rizzoti et al. 2013). From $14.5 \mathrm{dpc}$ and towards the end of gestation in the mouse, SOX9 is upregulated in the pituitary, exclusively in SOX2-positive cells. Both proteins will remain co-expressed postnatally in pituitary stem cells (Fauquier et al. 2008; Rizzoti et al. 2013). While SOX2 and SOX9 belong to the same group of transcriptional regulators, sequence homology assigns them to different sub-families (SOXB1 and SOXE, respectively); they therefore have different partners, target genes and hence, roles (Kamachi and Kondoh 2013). SOX9 is required for maintenance of different ectodermal stem cell populations, such as hair, retinal, neural crest, and neural stem cells (NSC) (Sarkar and Hochedlinger 2013). In the developing neuroepithelium, SOX9 is both required and sufficient for formation of multipotent NSC, seemingly given them the ability to give rise to glial cell types and not just neurons (Scott et al. 2010). In the adult, the protein is involved in the maintenance of NSC and their multipotentiality (Scott et al. 2010).

In the developing pituitary, we observe that up-regulation of SOX9 correlates with a decreased proliferative potential in pituitary progenitors, with the percentage of SOX2-positive proliferating cells reduced by a factor of two between 12.5 and 16.5 dpc (Fig. 2). In addition, lineage-tracing experiments, using either a Sox $9^{\text {ires-creERT2 }}$ allele or the $\operatorname{Sox} 2^{\text {creERT2 }}$ allele, but where it is induced coincident with the upregulation of SOX9 in pituitary progenitors, show that the SOX9;SOX2-positive progenitors also tend to differentiate less often (Rizzoti et al. 2013). Therefore, the expression of SOX9 correlates both with reduced levels of proliferation and differentiation, two characteristics of pituitary stem cells that distinguish them from embryonic progenitors. So far, deletion of the gene during pituitary development has not revealed a significant role for SOX9 in the gland before birth (unpublished data); therefore, its function in pituitary progenitors does not parallel what is observed in the developing CNS. Further investigations are now required to examine its function postnatally. Analysis of its target genes may be informative to characterise the transition between tissue progenitor and stem cell phenotypes. 


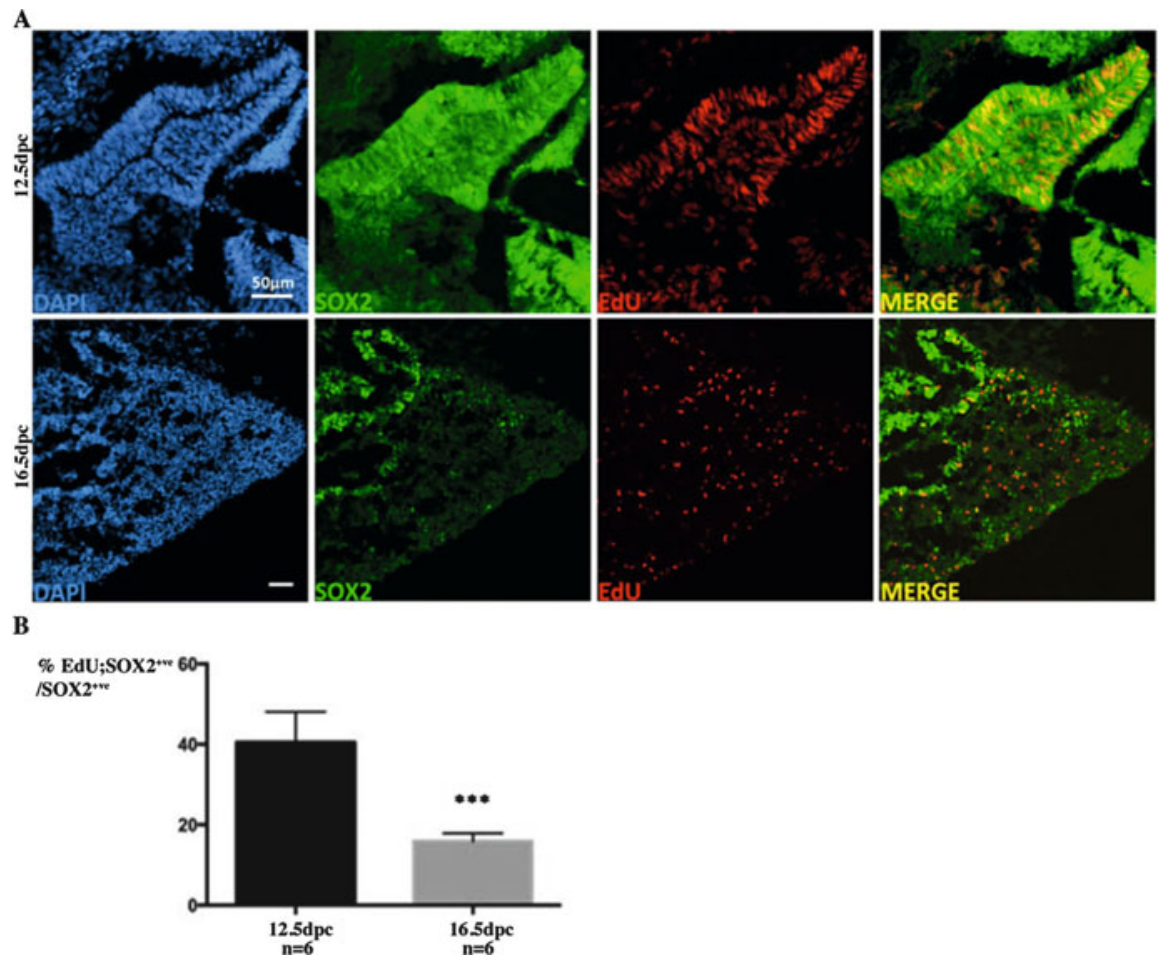

Fig. 2 Rate of proliferation of pituitary embryonic progenitors before and after SOX9 up-regulation. (a) Assessment of proliferative rates by incorporation of EdU at 12.5 and 16.5dpc. Immunofluorescence for SOX2 (green) and EdU-labelling (red) after 1 h00 EdU pulse. At $12.5 \mathrm{dpc}$ all cells express SOX2 and a high proportion is dividing. At $16.5 \mathrm{dpc}$, progenitors/stem cells are dorsally restricted to cells lining the cleft and proliferation is significantly reduced. (b) Quantification of EdU incorporation. At $12.5 \mathrm{dpc}, 40.5 \%(\mathrm{SD}=7.5 \mathrm{n}=6)$ of $\mathrm{SOX} 2^{+\mathrm{ve}}$ cells in RP have incorporated EdU, whereas at $16.5 \mathrm{dpc}$, as SOX9 is up-regulated, only $19.2 \%$ ( $\mathrm{SD}=2.1$, $\mathrm{n}=6$ ) do so (asterisks in $\mathbf{b}$ ?)

\section{Characterization of AdSC in the Hypothalamo-Pituitary Axis} (Fig. 3)

\section{Hypothalamus}

Initial investigations of cell proliferation patterns in the post-natal hypothalamus revealed the presence of dividing cells, in particular around the third ventricle, just above the ME. Cell proliferation could be stimulated by infusion of different factors, such as BDNF (Pencea et al. 2001), EFG and FGF (Xu et al. 2005), IGF (Perez-Martin et al. 2010) and CNTF (Kokoeva et al. 2005). In addition, labelretaining experiments suggested active neurogenesis in the hypothalamus (Kokoeva et al. 2005, 2007; Xu et al. 2005; Perez-Martin et al. 2010), defining a 


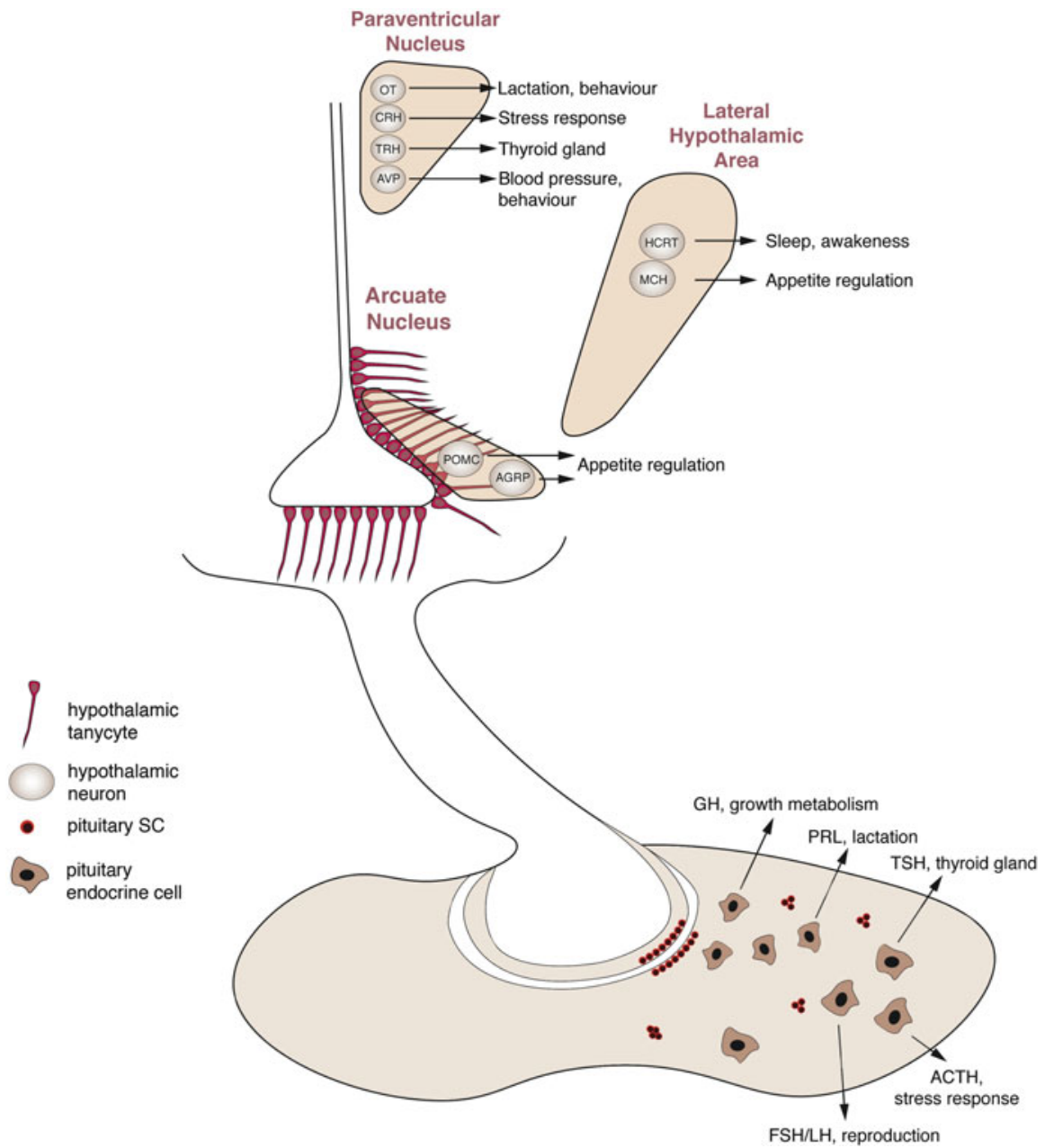

Fig. 3 Regenerative medicine in the hypothalamo-pituitary axis: endogenous stem cells and in vitro differentiated cell types. Endogenous stem cell (SC) populations (red) and differentiated progeny (brown) obtained in vitro are represented. In the hypothalamus, tanycytes, specialized glial cells located at the base of the third ventricle, form a diet-responsive stem cell population. In the pituitary, stem cells are present in the epithelium lining the cleft and are also scattered in the anterior lobe, sometimes as rosettes. Both hypothalamic neurons and pituitary endocrine cells have been obtained in vitro from ESC and iPSC. In the hypothalamus, transplantation of neurons could be used to modulate feeding behaviour to treat obesity for example, but the range of neurons obtained in vitro could potentially be used to manipulate a range of hypothalamic functions. In the pituitary, transplantation of endocrine cells would represent a significant improvement over existing replacement or substitution therapies 
third neurogenic niche in the brain along with the sub-ventricular zone of the lateral ventricles and the dentate gyrus of the hippocampus. Kokoeva et al. (2005) were the first to suggest that hypothalamic neurogenesis was physiologically relevant, as they demonstrated a role for newly generated neurons in feeding control. More recently, lineage tracing experiments have firmly established the existence of active hypothalamic neurogenesis and gliogenesis (Lee et al. 2012; Li et al. 2012; Haan et al. 2013; Robins et al. 2013a, b; see also Blackshaw 2016) Precise dissections of the third ventricle sub-ventricular zone revealed that $\alpha$-tanycytes are hypothalamic AdSC (Robins et al. 2013b); this area is also where cell proliferation is most efficiently stimulated by IGF infusion (Perez-Martin et al. 2010). WNT signalling appears to regulate tanycyte generation post-natally (Wang et al. 2012). In addition, it has been suggested that some stem cells may reside in the parenchyma (Robins et al. 2013a). Following the initial report by Kokoeva et al., investigations have mostly focused on the role of hypothalamic neurogenesis in feeding control (Lee et al. 2012; Li et al. 2012; McNay et al. 2012; Haan et al. 2013). Stem cells are responsive to diet and a high fat diet reproducibly impairs neurogenesis in the arcuate nucleus (Li et al. 2012; McNay et al. 2012; Lee et al. 2014). Further results strengthen the association between pathological weight gain and neurogenesis impairment. Leptin is a satiety hormone, secreted by adipose cells and transported to the hypothalamus where it participates in appetite regulation. Obesity is associated with leptin insensitivity and, interestingly, leptin deficiency in mice results in impaired neurogenesis (McNay et al. 2012). Moreover, it has been known for some time that obesity is associated with hypothalamic inflammation. As this inflammation precedes obesity onset, it is increasingly suspected to be the cause, rather than the consequence, of diet-induced metabolic disease (Valdearcos et al. 2015). The association of high fat diet, leptin deficiency and hypothalamic inflammation with impaired neurogenesis ( $\mathrm{Li}$ et al. 2012; McNay et al. 2012) further highlights the importance of neurogenesis in feeding control, all suggesting that manipulation of this process may have therapeutic benefits for metabolic syndromes.

In addition to feeding control, studies in seasonal mammals support a role for hypothalamic neurogenesis in the control of reproduction (Batailler et al. 2015; Ebling 2015). Moreover, there is now evidence that systemic aging is initiated by hypothalamic inflammation (Zhang et al. 2013). The relevant targets of this inflammation, initiated by microglia, are the GnRH neurons, causing them to secrete less GnRH. The authors show that this decrease in GnRH contributes to systemic aging and that it is associated with decreased neurogenesis in both the hypothalamus and hippocampus. Its contribution to these processes is so far unclear, but GnRH administration rescues both GnRH levels and neurogenesis, demonstrating at least a correlation (Zhang et al. 2013). It would now be of interest to investigate the contribution of hypothalamic SC in other life-changing, physiological contexts, such as puberty and pregnancy, where the organism needs to adapt to and trigger, in the case of puberty, a new physiological status. 


\section{Pituitary}

In the adult gland, the persistence of an epithelial cell layer lining the pituitary cleft (the remnant of the embryonic RP epithelium surrounding the lumen), and the maintenance of SOX2 and SOX9 expression in this epithelial cell layer, was a good argument for the persistence of a progenitor population (Fauquier et al. 2008). The capacity of these cells to form spheres or colonies in vitro, an assay used to characterize progenitors in different tissues further reinforced this hypothesis (Chen et al. 2005; Lepore et al. 2005; Fauquier et al. 2008). Recently, lineage tracing analysis using either Sox 2 or Sox $9^{\text {CreERT2 }}$ targeted alleles definitively demonstrated their presence in the adult (Andoniadou et al. 2013; Rizzoti et al. 2013; see also Vankelecom 2016).

Under normal physiological conditions, adult pituitary stem cells proliferate and differentiate very little, suggesting that most cell turnover is due to endocrine cell division (Fauquier et al. 2008; Andoniadou et al. 2013; Rizzoti et al. 2013). Induction of apoptosis upon cell division, using specific genetic tools, confirmed this hypothesis by demonstrating that corticotroph turnover relies on the proliferation of differentiated cells (Langlais et al. 2013). A physiological role for pituitary stem cells was initially suggested by studies investigating models of pituitary target organ ablation (Nolan and Levy 2006). It has been known for some time that ablation of the adrenals and/or gonads triggered a transient mitotic wave in the gland, followed by generation of increased numbers of endocrine cells; moreover, these were specifically the type that normally regulates the ablated organ. While differentiated endocrine cells can divide, but do so rarely, Nolan and Levy were the first to observe that, after adrenalectomy and/or gonadectomy, proliferation is essentially restricted to non-endocrine cells of an immature appearance. Moreover, double ablations do not have an additive proliferative effect, suggesting that a single population of undifferentiated cells responds to both adrenalectomy and gonadectomy (Nolan and Levy 2006). More recently, diphtheria toxin-mediated endocrine cell ablation experiments confirmed these results by showing a mobilization of SOX2-positive cells, with a transient induction of proliferation and, presumably, differentiation. The extent of endocrine cell regeneration was limited and initial endocrine cell numbers never fully recovered; however, this could indicate that a partial recovery is physiologically sufficient (Fu et al. 2012; Fu and Vankelecom 2012). Finally, lineage-tracing experiments performed after pituitary target organ ablation firmly demonstrated that AdSCs both proliferate and differentiate, exclusively to give rise to the required cell type, such as corticotrophs (Rizzoti et al. 2013). This finding definitively established the regenerative potential of pituitary stem cells but also showed that they seem to be mostly, and perhaps only, mobilized under physiological challenge. Dissection of the mechanisms underlying mobilization is now required to investigate whether it would be possible to directly stimulate stem cells for therapeutic purposes. Further investigation into different, more physiological "challenging" situations such as, for example, 
pregnancy and lactation will also be necessary to fully explore potential roles for AdSCs.

While stem cells appear quiescent under normal physiological situations, their proliferation or at least activation may also be involved in tumorigenesis. The WNT signalling pathway is an important regulator of embryonic development but also of many AdSC populations (see Andoniadou 2016). Moreover, deregulation of the pathway is associated with cancer formation, a notable example being colorectal tumors (Clevers and Nusse 2012). In mice, it had been shown that expression of a degradation-resistant form of $\beta$ catenin, an important transducer of WNT signalling, in RP induced the formation of tumors resembling the mostly pediatric pituitary craniopharyngiomas (Gaston-Massuet et al. 2011). Postnatal induction of this constitutively active form of $\beta$ catenin in SOX2-positive cells also resulted in tumor formation, demonstrating the tumor-forming potential of the AdSC compartment. Tumors were, however, not composed of mutant stem cells, which instead induced neighboring cells to form them by a paracrine mechanism (Andoniadou et al. 2013). In resected human pituitary adenomas, a side population could be isolated. SOX2 expression was upregulated and spheres could be formed, suggesting the presence of a SOX2-positive progenitor population in tumors (Mertens et al. 2015). However, the role of SOX2-positive cells in adenoma formation is at present unclear.

\section{In vitro Recapitulation of Ontogenesis in the Hypothalamo- Pituitary Axis (Fig. 3)}

Two different methods have mostly been used to direct ESC differentiation towards differentiated cell types: tri-dimensional floating aggregates with relatively minimal exogenous treatments, where cell interactions underlie self-patterning into a defined embryonic structure with spectacular results, such as formation of an optic cup realized in the lab of the late Yoshiki Sasai (Eiraku et al. 2011); and two-dimensional cultures where sequential exogenous treatments guide cells through subsequent embryonic fates. Both methods have been successfully used to reproduce the embryonic events described above and obtain both human and murine neuroendocrine and endocrine cells.

\section{Induction of Hypothalamic Identity from 3D ESC Aggregates}

Mouse ESC aggregates were initially assayed for hypothalamic neuron generation (Ohyama et al. 2005). Neural progenitor fate was first induced under serum-free conditions (Okabe et al. 1996), followed by SHH and BMP7 treatment that resulted in the generation of ventral hypothalamic neurons (Ohyama et al. 2005). In a later 
study, culture under strictly defined chemical conditions to minimize exogenous signals was shown to be key to obtain rostral-most hypothalamic character in mouse ESC aggregates, which adopt an embryonic neuroepithelium-like morphology because neural anterior fate is acquired by default in such conditions (Wataya et al. 2008). Removal of insulin was crucial as it was shown to activate the Akt pathway, which would otherwise inhibit hypothalamic induction. Further treatment with SHH induces rostro-ventral hypothalamic identity, with a strong expression of RAX. Selection and re-aggregation of RAX positive cells, without SHH addition, resulted in the differentiation of morphologically mature, secreting vasopressin neurons. Moreover, further treatment of the re-aggregated cells with SHH induces efficient differentiation of other types of hypothalamic neurons (Wataya et al. 2008; Merkle et al. 2015). Very recently, human ESC and iPSC were used to generate hypothalamic neurons in aggregates (Merkle et al. 2015; Wang et al. 2015), following the previously dribed protocol (Wataya et al. 2008). Hypothalamic neurons were successfully obtained, but important differences were noted. These included the requirement for insulin for initial aggregate survival, along with an Akt inhibitor (Merkle et al. 2015), whereas Wang et al. (2015) used SMAD inhibitors to inactivate BMP and TG $\beta /$ Nodal/Activin pathways to promote neural differentiation. The major types of hypothalamic neurons were obtained, and further culturing with supporting mouse glia showed that these adopted morphologies similar to their in vivo counterpart, suggesting a mature phenotype. However there is a large variability in induction efficiency between experiments (Merkle et al. 2015).

\section{Generation of Hypothalamic Neurons from 2D ESC Cultures}

Both Wang et al. (2015) and Merkle et al. (2015) subsequently developed 2D differentiation protocols to reduce culture duration, providing an easier substrate for expansion than individual aggregates and also reducing variability in differentiation rate. Human ESC and iPSC were induced toward a hypothalamic progenitor fate by sequentially performing dual SMAD inhibition while activating ventralizing SHH signalling (Merkle et al. 2015; Wang et al. 2015). Subsequently, posteriorizing WNT signals were blocked (Merkle et al. 2015) or the NOTCH pathway was inhibited (Wang et al. 2015) to induce arcuate-ventral fate. Further culture on cortical mouse glia supported neuronal differentiation and led to the generation of the major types of hypothalamic neurons. These showed both the expected morphology and neuropeptide expression (Merkle et al. 2015), whereas addition of BDNF induced differentiation of progenitors into functional neurons typical of the arcuate nucleus. This process was further enhanced by co-culture with mouse astrocytes (Wang et al. 2015). Neurons were then transplanted into newborn mouse brains. The human MCH and orexin cells were maintained in the adult where they displayed features resembling synapses with mouse neurons, suggesting functional integration (Merkle et al. 2015). 


\section{Induction of RP from 3D Aggregates}

Following their success with generation of hypothalamic-like tissue (Wataya et al. 2008), Suga et al. (2011) reasoned that, by further inducing rostral character, they should obtain a domain equivalent to the anterior neural ridge apposed to a neurectoderm-like tissue, where RP formation may be induced (Ochiai et al. 2015; see Suga 2016). Large ESC aggregates were made in growth factor-free medium in the presence of SHH agonist, resulting in formation of a superficial ectodermal layer surrounding a RAX-positive neurectodermal domain. Subsequently, ectodermal patches thickened, RP marker expression was induced, and invagination of RP-like structures was observed, more efficiently in the presence of both BMP and FGF (Ochiai et al. 2015). The positive action of these two factors fits with in vivo requirements, because these are secreted from the infundibulum and necessary for RP induction and maintenance, respectively (Ericson et al. 1998; Treier et al. 1998). Inhibition of NOTCH signalling resulted, as reported in vivo (Zhu et al. 2006; Kita et al. 2007), in efficient differentiation of corticotrophs, one of the earliest cell types to differentiate. Transplantation of differentiated aggregates under the kidney capsule in hypophysectomised mice improved cortisol deficiency symptoms, which demonstrated the functionality of the ESC-derived corticotrophs (Suga et al. 2011). Obtaining other endocrine cell types was initially less efficient (Suga et al. 2011); however, addition of BMP and FGF improves both corticotroph and Pit-1 lineage endocrine cell differentiation (Ochiai et al. 2015).

Induction of placodal identity and differentiation of endocrine cells from 2D cultures

Human ESC were used to devise a sequential protocol directing cells toward a placodal fate (Dincer et al. 2013; see Studer 2016). Dual SMAD inhibition was initially performed to impart neural fate, and subsequent de-repression in combination with FGF inhibition was sufficient for acquisition of placodal identity. Modulation of FGF, BMP and SHH pathways further allowed specification of lens, trigeminal and pituitary placode identity. As shown earlier (Suga et al. 2011), treatment with an $\mathrm{HH}$ agonist induced pituitary placode fate and subsequently an RP gene expression profile. Corticotroph differentiation followed, whereas differentiation of somatotrophs and gonadotrophs relied on NOTCH pathway inhibition. In vivo secretion was demonstrated after sub-cutaneous transplantation in mice (Dincer et al. 2013).

\section{Perspectives}

\section{Differentiation Strategies}

It takes a minimum of 18 days to observe ACTH-positive cells from ESC aggregates, and maturation of hypothalamic neurons can take much longer (Merkle 
et al. 2015). Moreover, the progression through different developmental stages implies some degree of heterogeneity in the culture. Finally, and probably in consequence, the percentage of desired cells obtained is often low. For disease modelling, drug screening and clinical use of these variables should be improved. Culture conditions can be modified and/or the starting cell type, as we will discuss here.

It has already been observed that co-culture with supporting cells, such as cortical glia (Merkle et al. 2015) and specifically astrocytes (Wang et al. 2015), improves differentiation rates of hypothalamic neurons. It has been proposed that co-culture with neurons may also help (Merkle et al. 2015). Differentiation of pituitary endocrine cells may similarly be improved by co-culture with folliculostellate cells, a heterogeneous population comprising stem cells but also endocrinesupporting cells (Allaerts and Vankelecom 2005) and/or endocrine cells. Different endocrine cell lines exist and one could examine whether co-culture with these might favor differentiation toward each particular cell type. In addition, generation of 3D pituitary mixed cell type-aggregates has been described in which tissue-like organization and endocrine secretions seem to mimic the in vivo situation; moreover, these characteristics are efficiently maintained over several weeks (Denef et al. 1989). Co-culture in these conditions may help progenitors to differentiate more efficiently.

In aggregates, the absence of vascularization may compromise endocrine differentiation and maturation, as observed in organoids, and affect cell survival more generally in the expanding structures (Lancaster and Knoblich 2014). There are, of course, many other structural and cellular components of the endogenous stem cell niche that are missing in these aggregates. Therefore, reconstitution of the stem cells' microenvironment in vitro has been the focus of several investigations. Biomaterials have been developed to support co-culture to supply vascularization, for example, but also to allow applications of factors, either extracellular matrix or signalling molecules. Recent and promising droplet-based microfluidic strategies have been described that can be used in either 3D or 2D cultures (Allazetta and Lutolf 2015). These in vitro micro-niches are of interest for drug screening because they are scalable, but they may also offer a suitable substrate to obtain cells for transplantation. Perhaps these would further allow organization into a pattern typical of the anterior pituitary.

Starting from pluripotent stem cells, either ESC or iPSC implies a long developmental "journey" to reach a mature terminally differentiated state. Since populations of progenitors have been characterized in both compartments of the hypothalamo-pituitary axis, a "short cut" would be to start from somatic cells that are then directly re-programmed into hypothalamic or pituitary specific stem cells. Similar protocols were initially described for NSCs (Kim et al. 2011; Ring et al. 2012; Thier et al. 2012) and many other cell types since. Self-renewal will be comparable in ESC and iPSC, but the differentiation potential is now limited to the cells of interest. This implies characterization of the factors necessary and sufficient to impart the desired identity upon re-programming. 


\section{Implantation in Homotypic Locations}

Once the cell types of interest have been efficiently generated in vitro, they can be transplanted back to restore function. Up to now, transplantations of either pituitary or hypothalamic ES-derived cells have been realised in heterotopic locations; under the kidney capsule (Suga et al. 2011), or subcutaneously (Dincer et al. 2013) for endocrine cells, and in the lateral ventricle or brain parenchyma for hypothalamic neurons (Merkle et al. 2015).

While Suga et al. (2011) successfully improved some hypophysectomy symptoms by implanting cells under the kidney capsule, the pituitary and hypothalamus are physically and functionally connected: proper regulation of endocrine secretions requires connection with the hypothalamus. In pilot experiments in the 1950s, Harris and collaborators indeed demonstrated that anterior pituitary transplantation away from its normal location, such as under the kidney capsule, resulted in chronic PRL secretion and essentially loss of secretion of the other hormones. In contrast, grafts implanted near the pituitary stalk, shortly after hypophysiectomy, resulted in regeneration of the portal system and this was associated with functional integration of the graft (Harris and Jacobsohn 1951). Therefore, transphenoidal endoscopic cell transplantation in the human pituitary close to the pituitary stalk should promote adequate integration and control (see Studer and Tabar 2016).

Hypothalamic neurons need to be able to make relevant connections, particularly those controlling the pituitary via the ME. Transplantations of cells or grafts have been realized in the hypothalamus with spectacular results. Placement of pre-optic area (POA) grafts containing GnRH neurons close to the ME successfully restores reproductive function in the gnrhl mutant hypogonadal mice, independently of the sex of the donor. As expected, success appears to rely on accession of GnRH axons to the ME (Gibson et al. 1984; Charlton 2004). Anterior hypothalamic implants comprising the suprachiasmatic nucleus restore periodicity in animals rendered arrhythmic by hypothalamic lesions (Sollars et al. 1995). More recently, immature hypothalamic neurons and progenitors were transplanted into the hypothalamic parenchyma of early postnatal brains of leptin receptor-deficient mice. These resulted in functional integration and partial restoration of leptin responsiveness in the adult (Czupryn et al. 2011). However, transplantations close to the ME might offer better results, because arcuate nucleus grafts transplanted into the third ventricle, close to the $\mathrm{ME}$, are associated with comparatively better anti-obesity effects in obese rats (Ono et al. 1990; Fetissov et al. 2000). Integration near a site where the blood-brain barrier is interrupted might allow access to peripheral signals, such as leptin in this context and, therefore, better functionality. All these studies show that hypothalamic implantation can restore function; therefore, they offer hope that stem cell-derived hypothalamic neurons transplanted near the $\mathrm{ME}$ would be successful. However, as demonstrated in mice, damage to the ME/stalk, such as that observed after traumatic brain injuries, is probably causative of pituitary deficiencies (Osterstock et al. 2014). Therefore, just as transplantation close to this site has been proposed to improve the functionality of both pituitary 
and hypothalamic transplants, care should be taken not to damage this fragile structure.

\section{Conclusion}

The generation of endocrine cells from ESC and their subsequent transplantation in vivo represent exciting progress towards the use of regenerative medicine to treat endocrine deficits or manipulate endocrine outputs. Improvement of differentiation efficiencies and transplantation in homotypic locations should in the near future demonstrate whether regenerative therapies are suitable for clinical use to treat neuro-endocrinological disorders.

Open Access This chapter is distributed under the terms of the Creative Commons Attribution 4.0 International License (http://creativecommons.org/licenses/by/4.0/), which permits use, duplication, adaptation, distribution and reproduction in any medium or format, as long as you give appropriate credit to the original author(s) and the source, a link is provided to the Creative Commons license and any changes made are indicated.

The images or other third party material in this chapter are included in the work's Creative Commons license, unless indicated otherwise in the credit line; if such material is not included in the work's Creative Commons license and the respective action is not permitted by statutory regulation, users will need to obtain permission from the license holder to duplicate, adapt or reproduce the material.

\section{References}

Alatzoglou KS, Webb EA, Le Tissier P, Dattani MT (2014) Isolated growth hormone deficiency (GHD) in childhood and adolescence: recent advances. Endocr Rev 35:376-432

Allaerts W, Vankelecom H (2005) History and perspectives of pituitary folliculo-stellate cell research. Eur J Endocrinol 153:1-12

Allazetta S, Lutolf MP (2015) Stem cell niche engineering through droplet microfluidics. Curr Opin Biotechnol 35:86-93

Andoniadou CL (2016) Pituitary stem cells during normal physiology and disease. In: Pfaff D, Christen Y (eds) Stem cells in neuroendocrinology. Springer, Heidelberg

Andoniadou CL, Matsushima D, Mousavy Gharavy SN, Signore M, Mackintosh AI, Schaeffer M, Gaston-Massuet C, Mollard P, Jacques TS, Le Tissier P, Dattani MT, Pevny LH, MartinezBarbera JP (2013) Sox2(+) stem/progenitor cells in the adult mouse pituitary support organ homeostasis and have tumor-inducing potential. Cell Stem Cell 13:433-445

Batailler M, Derouet L, Butruille L, Migaud M (2015) Sensitivity to the photoperiod and potential migratory features of neuroblasts in the adult sheep hypothalamus. Brain Struct Funct doi:10.1007/ss00429-015-1101-0

Bedont JL, Newman EA, Blackshaw S (2015) Patterning, specification, and differentiation in the developing hypothalamus. Wiley interdisciplinary reviews. Dev Biol 4:445-468

Blackshaw S (2016) Regulation of body weight and metabolism by tanycyte-derived neurogenesis in young adult mice. In: Pfaff D, Christen Y (eds) Stem cells in neuroendocrinology. Springer, Heidelberg 
Bolborea M, Dale N (2013) Hypothalamic tanycytes: potential roles in the control of feeding and energy balance. Trends Neurosci 36:91-100

Castinetti F, Davis SW, Brue T, Camper SA (2011) Pituitary stem cell update and potential implications for treating hypopituitarism. Endocr Rev 32:453-471

Charlton H (2004) Neural transplantation in hypogonadal (hpg) mice-physiology and neurobiology. Reproduction 127:3-12

Chen J, Hersmus N, Van Duppen V, Caesens P, Denef C, Vankelecom H (2005) The adult pituitary contains a cell population displaying stem/progenitor cell and early embryonic characteristics. Endocrinology 146:3985-3998

Clevers H, Nusse R (2012) Wnt/beta-catenin signaling and disease. Cell 149:1192-1205

Czupryn A, Zhou YD, Chen X, McNay D, Anderson MP, Flier JS, Macklis JD (2011) Transplanted hypothalamic neurons restore leptin signaling and ameliorate obesity in $\mathrm{db} / \mathrm{db}$ mice. Science 334:1133-1137

Davis SW, Mortensen AH, Camper SA (2011) Birthdating studies reshape models for pituitary gland cell specification. Dev Biol 352:215-227

Denef C, Maertens P, Allaerts W, Mignon A, Robberecht W, Swennen L, Carmeliet P (1989) Cellto-cell communication in peptide target cells of anterior pituitary. Methods Enzymol 168: $47-71$

Dincer Z, Piao J, Niu L, Ganat Y, Kriks S, Zimmer B, Shi SH, Tabar V, Studer L (2013) Specification of functional cranial placode derivatives from human pluripotent stem cells. Cell Rep 5:1387-1402

Drouin J (2016) Epigenetic mechanisms of pituitary cell fate specification. In: Pfaff D, Christen Y (eds) Stem cells in neuroendocrinology. Springer, Heidelberg

Ebling FJ (2015) Hypothalamic control of seasonal changes in food intake and body weight. Front Neuroendocrinol 37:97-107

Eiraku M, Takata N, Ishibashi H, Kawada M, Sakakura E, Okuda S, Sekiguchi K, Adachi T, Sasai Y (2011) Self-organizing optic-cup morphogenesis in three-dimensional culture. Nature 472:51-56

Ericson J, Norlin S, Jessell TM, Edlund T (1998) Integrated FGF and BMP signaling controls the progression of progenitor cell differentiation and the emergence of pattern in the embryonic anterior pituitary. Development 125:1005-1015

Fauquier T, Rizzoti K, Dattani M, Lovell-Badge R, Robinson IC (2008) SOX2-expressing progenitor cells generate all of the major cell types in the adult mouse pituitary gland. Proc Natl Acad Sci USA 105:2907-2912

Fetissov SO, Gerozissis K, Orosco M, Nicolaidis S (2000) Synergistic effect of arcuate and raphe nuclei graft to alleviate insulinemia and obesity in Zucker rats. Acta Diabetol 37:65-70

Fox IJ, Daley GQ, Goldman SA, Huard J, Kamp TJ, Trucco M (2014) Stem cell therapy. Use of differentiated pluripotent stem cells as replacement therapy for treating disease. Science 345: 1247391

French A et al (2015) Enabling consistency in pluripotent stem cell-derived products for research and development and clinical applications through material standards. Stem Cells Translat Med 4:217-223

Fu Q, Vankelecom H (2012) Regenerative capacity of the adult pituitary: multiple mechanisms of lactotrope restoration after transgenic ablation. Stem Cells Dev 21:3245-3257

Fu Q, Gremeaux L, Luque RM, Liekens D, Chen J, Buch T, Waisman A, Kineman R, Vankelecom H (2012) The adult pituitary shows stem/progenitor cell activation in response to injury and is capable of regeneration. Endocrinology 153:3224-3235

Gaston-Massuet C, Andoniadou CL, Signore M, Jayakody SA, Charolidi N, Kyeyune R, Vernay B, Jacques TS, Taketo MM, Le Tissier P, Dattani MT, Martinez-Barbera JP (2011) Increased Wingless (Wnt) signaling in pituitary progenitor/stem cells gives rise to pituitary tumors in mice and humans. Proc Natl Acad Sci USA 108:11482-11487 
Gibson MJ, Krieger DT, Charlton HM, Zimmerman EA, Silverman AJ, Perlow MJ (1984) Mating and pregnancy can occur in genetically hypogonadal mice with preoptic area brain grafts. Science 225:949-951

Goto M, Hojo M, Ando M, Kita A, Kitagawa M, Ohtsuka T, Kageyama R, Miyamoto S (2015) Hes1 and Hes5 are required for differentiation of pituicytes and formation of the neurohypophysis in pituitary development. Brain Res 1625:206-217

Haan N, Goodman T, Najdi-Samiei A, Stratford CM, Rice R, El Agha E, Bellusci S, Hajihosseini MK (2013) Fgf10-expressing tanycytes add new neurons to the appetite/energy-balance regulating centers of the postnatal and adult hypothalamus. J Neurosci 33:6170-6180

Hannon MJ, Crowley RK, Behan LA, O'Sullivan EP, O’Brien MM, Sherlock M, Rawluk D, O'Dwyer R, Tormey W, Thompson CJ (2013) Acute glucocorticoid deficiency and diabetes insipidus are common after acute traumatic brain injury and predict mortality. $\mathrm{J}$ Clin Endocrinol Metab 98:3229-3237

Harris GW, Jacobsohn D (1951) Functional grafts of the anterior pituitary gland. J Physiol 113: $35 p-36 p$

Himes AD, Raetzman LT (2009) Premature differentiation and aberrant movement of pituitary cells lacking both Hes1 and Prop1. Dev Biol 325:151-161

Hsu PD, Lander ES, Zhang F (2014) Development and applications of CRISPR-Cas9 for genome engineering. Cell 157:1262-1278

Huch M, Koo BK (2015) Modeling mouse and human development using organoid cultures. Development 142:3113-3125

Japon MA, Rubinstein M, Low MJ (1994) In situ hybridization analysis of anterior pituitary hormone gene expression during fetal mouse development. J Histochem Cytochem 42: $1117-1125$

Kamachi Y, Kondoh H (2013) Sox proteins: regulators of cell fate specification and differentiation. Development 140:4129-4144

Kelberman D, Rizzoti K, Lovell-Badge R, Robinson IC, Dattani MT (2009) Genetic regulation of pituitary gland development in human and mouse. Endocr Rev 30:790-829

Khonsari RH et al (2013) The buccohypophyseal canal is an ancestral vertebrate trait maintained by modulation in sonic hedgehog signaling. BMC Biol 11:27

Kim J, Efe JA, Zhu S, Talantova M, Yuan X, Wang S, Lipton SA, Zhang K, Ding S (2011) Direct reprogramming of mouse fibroblasts to neural progenitors. Proc Natl Acad Sci USA 108:7838-7843

Kita A, Imayoshi I, Hojo M, Kitagawa M, Kokubu H, Ohsawa R, Ohtsuka T, Kageyama R, Hashimoto N (2007) Hes1 and Hes5 control the progenitor pool, intermediate lobe specification, and posterior lobe formation in the pituitary development. Mol Endocrinol 21:1458-1466

Kokoeva MV, Yin H, Flier JS (2005) Neurogenesis in the hypothalamus of adult mice: potential role in energy balance. Science 310:679-683

Kokoeva MV, Yin H, Flier JS (2007) Evidence for constitutive neural cell proliferation in the adult murine hypothalamus. J Comp Neurol 505:209-220

Konadhode RR, Pelluru D, Shiromani PJ (2014) Neurons containing orexin or melanin concentrating hormone reciprocally regulate wake and sleep. Front Syst Neuro 8:244

Lancaster MA, Knoblich JA (2014) Organogenesis in a dish: modeling development and disease using organoid technologies. Science 345:1247125

Langlais D, Couture C, Kmita M, Drouin J (2013) Adult pituitary cell maintenance: lineagespecific contribution of self-duplication. Mol Endocrinol 27:1103-1112

Lee DA et al (2014) Dietary and sex-specific factors regulate hypothalamic neurogenesis in young adult mice. Front Neurosci 8:157

Lee DA, Bedont JL, Pak T, Wang H, Song J, Miranda-Angulo A, Takiar V, Charubhumi V, Balordi F, Takebayashi H, Aja S, Ford E, Fishell G, Blackshaw S (2012) Tanycytes of the hypothalamic median eminence form a diet-responsive neurogenic niche. Nat Neurosci 15: 700-702 
Lepore DA, Roeszler K, Wagner J, Ross SA, Bauer K, Thomas PQ (2005) Identification and enrichment of colony-forming cells from the adult murine pituitary. Exp Cell Res 308:166-176

Levy A (2002) Physiological implications of pituitary trophic activity. J Endocrinol 174:147-155

Li J, Tang Y, Cai D (2012) IKKbeta/NF-kappaB disrupts adult hypothalamic neural stem cells to mediate a neurodegenerative mechanism of dietary obesity and pre-diabetes. Nat Cell Biol 14: 999-1012

Lu F, Kar D, Gruenig N, Zhang ZW, Cousins N, Rodgers HM, Swindell EC, Jamrich M, Schuurmans C, Mathers PH, Kurrasch DM (2013) Rax is a selector gene for mediobasal hypothalamic cell types. J Neurosci 33:259-272

McNay DE, Briancon N, Kokoeva MV, Maratos-Flier E, Flier JS (2012) Remodeling of the arcuate nucleus energy-balance circuit is inhibited in obese mice. J Clin Invest 122:142-152

McShane SG, Mole MA, Savery D, Greene ND, Tam PP, Copp AJ (2015) Cellular basis of neuroepithelial bending during mouse spinal neural tube closure. Dev Biol 404:113-124

Merkle FT, Maroof A, Wataya T, Sasai Y, Studer L, Eggan K, Schier AF (2015) Generation of neuropeptidergic hypothalamic neurons from human pluripotent stem cells. Development 142: 633-643

Mertens FM, Gremeaux L, Chen J, Fu Q, Willems C, Roose H, Govaere O, Roskams T, Cristina C, Becu-Villalobos D, Jorissen M, Vander Poorten V, Bex M, van Loon J, Vankelecom H (2015) Pituitary tumors contain a side population with tumor stem cell-associated characteristics. Endocr Relat Cancer 22:481-504

Mollard P, Hodson DJ, Lafont C, Rizzoti K, Drouin J (2012) A tridimensional view of pituitary development and function. Trends Endocrinol Metab 23:261-269

Nolan LA, Levy A (2006) A population of non-luteinising hormone/non-adrenocorticotrophic hormone-positive cells in the male rat anterior pituitary responds mitotically to both gonadectomy and adrenalectomy. J Neuroendocrinol 18:655-661

Ochiai H, Suga H, Yamada T, Sakakibara M, Kasai T, Ozone C, Ogawa K, Goto M, Banno R, Tsunekawa S, Sugimura Y, Arima H, Oiso Y (2015) BMP4 and FGF strongly induce differentiation of mouse ES cells into oral ectoderm. Stem Cell Res 15:290-298

Ohyama K, Ellis P, Kimura S, Placzek M (2005) Directed differentiation of neural cells to hypothalamic dopaminergic neurons. Development 132:5185-5197

Okabe S, Forsberg-Nilsson K, Spiro AC, Segal M, McKay RD (1996) Development of neuronal precursor cells and functional postmitotic neurons from embryonic stem cells in vitro. Mech Dev 59:89-102

Ono K, Kawamura K, Shimizu N, Ito C, Plata-Salaman CR, Ogawa N, Oomura Y (1990) Fetal hypothalamic brain grafts to the ventromedial hypothalamic obese rats: an immunohistochemical, electrophysiological and behavioral study. Brain Res Bull 24:89-96

Osterstock G, El Yandouzi T, Romano N, Carmignac D, Langlet F, Coutry N, Guillou A, Schaeffer M, Chauvet N, Vanacker C, Galibert E, Dehouck B, Robinson IC, Prevot V, Mollard P, Plesnila N, Mery PF (2014) Sustained alterations of hypothalamic tanycytes during posttraumatic hypopituitarism in male mice. Endocrinology 155:1887-1898

Pearson CA, Placzek M (2013) Development of the medial hypothalamus: forming a functional hypothalamic-neurohypophyseal interface. Curr Top Dev Biol 106:49-88

Pearson CA, Ohyama K, Manning L, Aghamohammadzadeh S, Sang H, Placzek M (2011) FGF-dependent midline-derived progenitor cells in hypothalamic infundibular development. Development 138:2613-2624

Pencea V, Bingaman KD, Wiegand SJ, Luskin MB (2001) Infusion of brain-derived neurotrophic factor into the lateral ventricle of the adult rat leads to new neurons in the parenchyma of the striatum, septum, thalamus, and hypothalamus. J Neurosci 21:6706-6717

Perez-Martin M, Cifuentes M, Grondona JM, Lopez-Avalos MD, Gomez-Pinedo U, GarciaVerdugo JM, Fernandez-Llebrez P (2010) IGF-I stimulates neurogenesis in the hypothalamus of adult rats. Eur J Neurosci 31:1533-1548

Prevot V, Bellefontaine N, Baroncini M, Sharif A, Hanchate NK, Parkash J, Campagne C, de Seranno S (2010) Gonadotrophin-releasing hormone nerve terminals, tanycytes and 
neurohaemal junction remodelling in the adult median eminence: functional consequences for reproduction and dynamic role of vascular endothelial cells. J Neuroendocrinol 22:639-649

Ring KL, Tong LM, Balestra ME, Javier R, Andrews-Zwilling Y, Li G, Walker D, Zhang WR, Kreitzer AC, Huang Y (2012) Direct reprogramming of mouse and human fibroblasts into multipotent neural stem cells with a single factor. Cell Stem Cell 11:100-109

Rizzoti K (2015) Genetic regulation of murine pituitary development. J Mol Endocrinol 54: R55-R73

Rizzoti K, Brunelli S, Carmignac D, Thomas PQ, Robinson IC, Lovell-Badge R (2004) SOX3 is required during the formation of the hypothalamo-pituitary axis. Nat Genet 36:247-255

Rizzoti K, Akiyama H, Lovell-Badge R (2013) Mobilized adult pituitary stem cells contribute to endocrine regeneration in response to physiological demand. Cell Stem Cell 13:419-432

Robins SC, Trudel E, Rotondi O, Liu X, Djogo T, Kryzskaya D, Bourque CW, Kokoeva MV (2013a) Evidence for NG2-glia derived, adult-born functional neurons in the hypothalamus. PLoS One 8:e78236

Robins SC, Stewart I, McNay DE, Taylor V, Giachino C, Goetz M, Ninkovic J, Briancon N, Maratos-Flier E, Flier JS, Kokoeva MV, Placzek M (2013b) alpha-Tanycytes of the adult hypothalamic third ventricle include distinct populations of FGF-responsive neural progenitors. Nat Commun 4:2049

Sadagurski M, Landeryou T, Cady G, Kopchick JJ, List EO, Berryman DE, Bartke A, Miller RA (2015) Growth hormone modulates hypothalamic inflammation in long-lived pituitary dwarf mice. Aging Cell 14:1045-1054

Salvatierra J, Lee DA, Zibetti C, Duran-Moreno M, Yoo S, Newman EA, Wang H, Bedont JL, de Melo J, Miranda-Angulo AL, Gil-Perotin S, Garcia-Verdugo JM, Blackshaw S (2014) The LIM homeodomain factor Lhx2 is required for hypothalamic tanycyte specification and differentiation. J Neurosci 34:16809-16820

Sarkar A, Hochedlinger K (2013) The sox family of transcription factors: versatile regulators of stem and progenitor cell fate. Cell Stem Cell 12:15-30

Schlosser G, Patthey C, Shimeld SM (2014) The evolutionary history of vertebrate cranial placodes II. Evolution of ectodermal patterning. Dev Biol 389:98-119

Schneeberger M, Gomis R, Claret M (2014) Hypothalamic and brainstem neuronal circuits controlling homeostatic energy balance. J Endocrinol 220:T25-T46

Schwartz SD, Regillo CD, Lam BL, Eliott D, Rosenfeld PJ, Gregori NZ, Hubschman JP, Davis JL, Heilwell G, Spirn M, Maguire J, Gay R, Bateman J, Ostrick RM, Morris D, Vincent M, Anglade E, Del Priore LV, Lanza R (2015) Human embryonic stem cell-derived retinal pigment epithelium in patients with age-related macular degeneration and Stargardt's macular dystrophy: follow-up of two open-label phase 1/2 studies. Lancet 385:509-516

Scott CE, Wynn SL, Sesay A, Cruz C, Cheung M, Gomez Gaviro MV, Booth S, Gao B, Cheah KS, Lovell-Badge R, Briscoe J (2010) SOX9 induces and maintains neural stem cells. Nat Neurosci 13:1181-1189

Shamir ER, Ewald AJ (2014) Three-dimensional organotypic culture: experimental models of mammalian biology and disease. Nat Rev Mol Cell Biol 15:647-664

Sollars PJ, Kimble DP, Pickard GE (1995) Restoration of circadian behavior by anterior hypothalamic heterografts. J Neurosci 15:2109-2122

Soukup V, Horacek I, Cerny R (2013) Development and evolution of the vertebrate primary mouth. J Anat 222:79-99

Steinbeck JA, Studer L (2015) Moving stem cells to the clinic: potential and limitations for brain repair. Neuron 86:187-206

Stevenson EL, Corella KM, Chung WC (2013) Ontogenesis of gonadotropin-releasing hormone neurons: a model for hypothalamic neuroendocrine cell development. Front Endocrinol 4:89

Studer L (2016) Human pluripotent-derived lineages for repairing hypopituitarism. In: Pfaff D, Christen Y (eds) Stem cells in neuroendocrinology. Springer, Heidelberg

Studer L, Tabar V (2016) Human pluripotent-derived lineages for repairing hypopituitarism. In: Pfaff D, Christen Y (eds) Stem cells in neuroendocrinology. Springer, Heidelberg 
Suga H (2016) Recapitulating hypothalamus and pituitary development using ES/iPS cells. In: Pfaff D, Christen Y (eds) Stem cells in neuroendocrinology. Springer, Heidelberg

Suga H, Kadoshima T, Minaguchi M, Ohgushi M, Soen M, Nakano T, Takata N, Wataya T, Muguruma K, Miyoshi H, Yonemura S, Oiso Y, Sasai Y (2011) Self-formation of functional adenohypophysis in three-dimensional culture. Nature 480:57-62

Takahashi K, Yamanaka S (2006) Induction of pluripotent stem cells from mouse embryonic and adult fibroblast cultures by defined factors. Cell 126:663-676

Thier M, Worsdorfer P, Lakes YB, Gorris R, Herms S, Opitz T, Seiferling D, Quandel T, Hoffmann P, Nothen MM, Brustle O, Edenhofer F (2012) Direct conversion of fibroblasts into stably expandable neural stem cells. Cell Stem Cell 10:473-479

Treier M, Gleiberman AS, O'Connell SM, Szeto DP, McMahon JA, McMahon AP, Rosenfeld MG (1998) Multistep signaling requirements for pituitary organogenesis in vivo. Genes Dev 12: $1691-1704$

Trowe MO, Zhao L, Weiss AC, Christoffels V, Epstein DJ, Kispert A (2013) Inhibition of Sox2dependent activation of Shh in the ventral diencephalon by Tbx3 is required for formation of the neurohypophysis. Development 140:2299-2309

Valdearcos M, Xu AW, Koliwad SK (2015) Hypothalamic inflammation in the control of metabolic function. Annu Rev Physiol 77:131-160

van de Wetering $M$ et al (2015) Prospective derivation of a living organoid biobank of colorectal cancer patients. Cell 161:933-945

Vankelecom H (2016) Pituitary stem cells: quest for hidden functions. In: Pfaff D, Christen Y (eds) Stem cells in neuroendocrinology. Springer, Heidelberg

Vierbuchen T, Wernig M (2012) Molecular roadblocks for cellular reprogramming. Mol Cell 47: $827-838$

Wang X et al (2012) Wnt signaling regulates postembryonic hypothalamic progenitor differentiation. Dev Cell 23:624-636

Wang Y, Martin JF, Bai CB (2010) Direct and indirect requirements of Shh/Gli signaling in early pituitary development. Dev Biol 348:199-209

Wang L, Meece K, Williams DJ, Lo KA, Zimmer M, Heinrich G, Martin Carli J, Leduc CA, Sun L, Zeltser LM, Freeby M, Goland R, Tsang SH, Wardlaw SL, Egli D, Leibel RL (2015) Differentiation of hypothalamic-like neurons from human pluripotent stem cells. J Clin Invest 125:796-808

Wataya T, Ando S, Muguruma K, Ikeda H, Watanabe K, Eiraku M, Kawada M, Takahashi J, Hashimoto N, Sasai Y (2008) Minimization of exogenous signals in ES cell culture induces rostral hypothalamic differentiation. Proc Natl Acad Sci USA 105:11796-11801

Xu Y, Tamamaki N, Noda T, Kimura K, Itokazu Y, Matsumoto N, Dezawa M, Ide C (2005) Neurogenesis in the ependymal layer of the adult rat 3rd ventricle. Exp Neurol 192:251-264

Zhang G, Li J, Purkayastha S, Tang Y, Zhang H, Yin Y, Li B, Liu G, Cai D (2013) Hypothalamic programming of systemic ageing involving IKK-beta, NF-kappaB and GnRH. Nature 497: 211-216

Zhao L, Zevallos SE, Rizzoti K, Jeong Y, Lovell-Badge R, Epstein DJ (2012) Disruption of SoxB1dependent sonic hedgehog expression in the hypothalamus causes septo-optic dysplasia. Dev Cell 22:585-596

Zhu X, Zhang J, Tollkuhn J, Ohsawa R, Bresnick EH, Guillemot F, Kageyama R, Rosenfeld MG (2006) Sustained Notch signaling in progenitors is required for sequential emergence of distinct cell lineages during organogenesis. Genes Dev 20:2739-2753 